\title{
Use of instability curves for the assessment of post- liquefaction stability and deformation of sloping grounds
}

\author{
Document Version \\ Accepted author manuscript
}

Link to publication record in Manchester Research Explorer

\section{Citation for published version (APA):}

Ismael, B., Lombardi, D., Bhattacharya, S., \& Syed, A. S. M. (2019). Use of instability curves for the assessment of post-liquefaction stability and deformation of sloping grounds. Engineering Geology.

\section{Published in:}

Engineering Geology

\section{Citing this paper}

Please note that where the full-text provided on Manchester Research Explorer is the Author Accepted Manuscript or Proof version this may differ from the final Published version. If citing, it is advised that you check and use the publisher's definitive version.

\section{General rights}

Copyright and moral rights for the publications made accessible in the Research Explorer are retained by the authors and/or other copyright owners and it is a condition of accessing publications that users recognise and abide by the legal requirements associated with these rights.

\section{Takedown policy}

If you believe that this document breaches copyright please refer to the University of Manchester's Takedown Procedures [http://man.ac.uk/04Y6Bo] or contact uml.scholarlycommunications@manchester.ac.uk providing relevant details, so we can investigate your claim.

\section{OPEN ACCESS}


This manuscript has been accepted for publication in Engineering Geology

\title{
Use of instability curves for the assessment of post-liquefaction stability and deformation of sloping grounds
}

\author{
Bashar Ismael $^{a}$, Domenico Lombardi ${ }^{b} \dagger$, Subhamoy \\ Bhattacharya $^{c}$, Syed Mohammed Ahmad ${ }^{d}$ \\ ${ }^{a}$ bashar.ismael@manchester.ac.uk \\ ${ }^{b}$ domenico.lombardi@manchester.ac.uk \\ ${ }^{c}$ s.bhattacharya@surrey.ac.uk \\ ${ }^{d}$ mohammed.ahmad.syed@manchester.ac.uk
}

${ }^{a, b, d}$ Department of Mechanical Aerospace and Civil Engineering, The University of Manchester, 76 Sackville St, Manchester M1 3NJ, UK

${ }^{c}$ Department of Civil and Environmental Engineering, University of Surrey, Stag Hill, Guildford, GU2 7XH, UK

$\dagger$ Corresponding author 
$1 \quad$ Highlights

- Use of multi-stage triaxial tests to investigate the post-cyclic behaviour of liquefied sand

- Derivation of instability curves for assessment of post-cyclic deformation of liquefied sloping grounds

- Demonstration of use of instability curves through real case study of post-liquefaction failure of Lower San Fernando Dam 


\begin{abstract}
The paper presents a simplified approach to determine the post-cyclic deformation of liquefied sloping grounds. The approach uses instability curves derived from undrained multi-stage (cyclic+monotonic) triaxial tests. It is shown that the salient aspects of the post-liquefaction deformation can be expressed as a function of the state parameter $\psi$, defined as the void ratio difference between the current state of the soil and its critical state at the same mean stress level, and amplitude of accumulated cyclic strain. As the proposed approach predicts deformations, rather than residual strength or factor of safety, the method can be used for the definition of the performance criteria following a performance-based design approach. The application of the proposed method is illustrated through a real case study.
\end{abstract}

Keywords: slopes; post-liquefaction; dilatancy; critical state, state parameter, performance-based design. 


\section{Introduction}

Soil liquefaction is a phenomenon wherein a mass of saturated soil temporarily loses its strength due to the development of excess pore-water pressure and consequent reduction of effective stress. Liquefaction is commonly observed in reclaimed lands (Elgamal et al., 1996) and young alluvial sediments (Pokhrel et al. , 2013) after major earthquakes.

The first documented cases of liquefaction-induced damage date back to the 1920s and involved quasi-static failures of coastal flow slides and hydraulic-fill dams (see Hazen, 1918, 1920; Middlebrooks, 1940; Koppejan et al., 1948; Seed, 1979). Similar failures have been observed ever since especially after major earthquakes (Broughton et al., 2001; Lee e al., 2004; Obermeier et al., 2005; Papathanassiou et al., 2016; Huang et al., 2018).

Terzaghi \& Peck (1948) used the expression 'spontaneous liquefaction' to describe to the process of 'sudden decrease of shearing resistance of a quick sand from its normal value to almost zero with the aid of seepage pressure'. Youd (1973) investigated the 'transformation of a granular material from a solid into a liquefied state as a consequence of increased pore-water pressures'. Castro \& Poulos (1977) used the concept of critical void ratio, introduced by Casagrande (1936) to define the ultimate condition reached by soils subjected to shearing, to distinguish between flow liquefaction, defined as the 'phenomenon wherein saturated sand loses a large percentage of its shear resistance and flows in a manner resembling a liquid', and cyclic mobility, defined as the 'progressive softening of a saturated sand specimen when subjected to cyclic loading'. The difference between flow liquefaction and cyclic 
mobility was illustrated by means of the state diagram reproduced in Figure 1. The continuous line in the state diagram, named Steady State Line (SSL) by Castro \& Poulos (1977), depicts the locus of void ratios attained by a soil when continuously sheared in undrained condition at constant void and stress ratios. As it can be seen the SSL also represents the boundary between contractive and dilative soils. Specifically, a state above the SSL is contractive as the soil tends to reduce in volume during monotonic/cyclic undrained shearing. However, owing to the undrained condition and consequent zero volume changes, the state moves horizontally to the left, until it intersects the SSL. For a very loose soil, the reduction of effective stress may reach a very low value resulting in the soil to flow like a heavy viscous fluid (ie, line C-A in Figure 1). Conversely, a state below the SSL is dilative as the soil tends to increase in volume upon monotonic shearing. The undrained condition implies that the state has to move horizontally to the right in the direction of increasing effective stresses, ie, path D-E in Figure 1. It is worth noting that in dilative soils the undrained strength is always greater than that exhibited during drained shearing, thus preventing the onset of liquefaction under undrained monotonic shearing. However, if the same dilative soil is subjected to undrained cyclic loading, the state moves to the left as it were contractive, and the effective stress may potentially reduce to zero if a sufficient number of cycles are applied or cyclic shear stresses are large enough (ie, path D-B in Figure 1). Evidently the application of cyclic stresses, such as those induced by earthquakes, waves, explosions, etc., may lead to liquefaction despite the fact that the soil exhibits an initial dilative behaviour. 


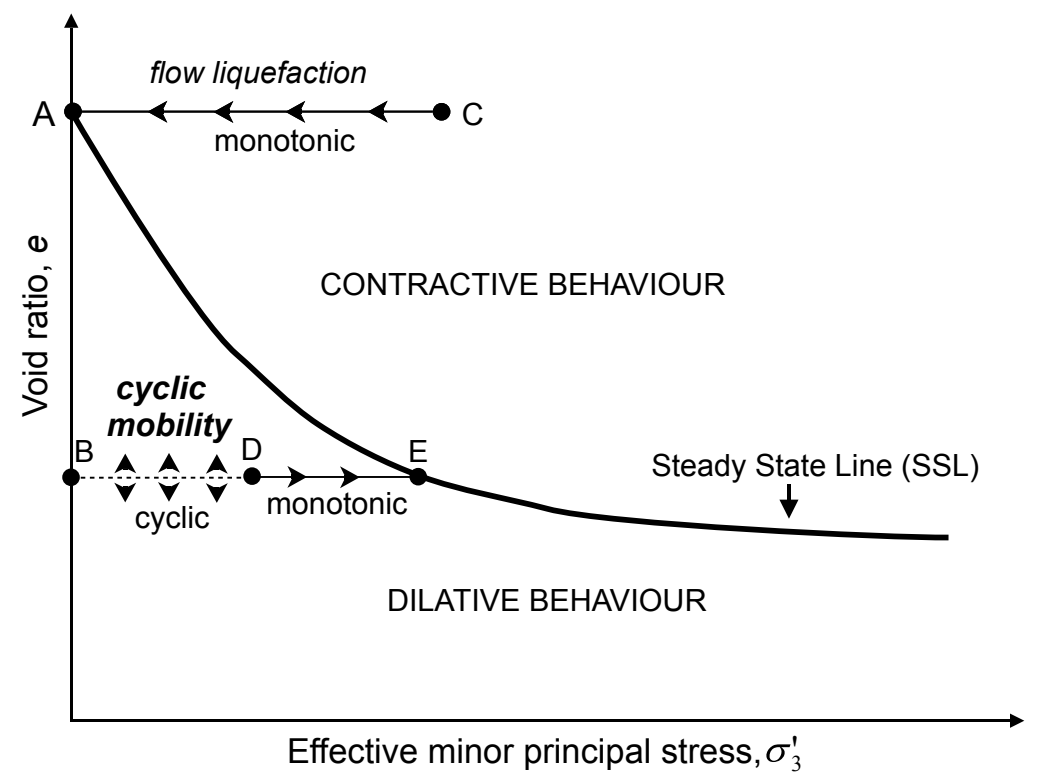

Figure 1: Definition of flow liquefaction and cyclic mobility in the state diagram (after Castro \& Poulos (1977))

Awareness of seismically-induced liquefaction as a major seismic hazard became evident only after the 1964 Niigata earthquake (Japan) and 1964 Alaska earthquakes (US), where the resulting widespread damage was attributed to the liquefaction of loose sand deposits found in reclamation and coastal areas (see Yamada, 1966; Seed \& Idriss, 1967; Seed, 1987). Extensive research on the topic has proliferated ever since, including different techniques and methodologies for example using statistical methods or using dynamic field compaction (see Shen et al., 2019a,b) or probabilistic methods (e.g., Juang et al. (2017)), resulting in better understanding of the phenomenon and development of semi-empirical procedures for assessment of liquefaction susceptibility, which are now included in many building codes. Once the soil liquefies, the degree of deformation, and consequently of damage, depends largely on the post-liquefaction response of the liquefied soil. 
Early works by Yoshida et al. (1994), Yasuda et al. (1994), Vaid \& Thomas (1995), and Kiku \& Tsujino (1996) pointed out that liquefied soils exhibited dilative behaviour upon undrained shearing irrespective of their initial states and void ratios. This dilative response resulted in a strain-hardening behaviour whereby the liquefied soil gradually mobilised increasing strength and stiffness upon shearing. Kokusho et al. (2004) investigated the effect of different particle gradations on the post-liquefaction undrained behaviour of sands, concluding that well-graded soils developed higher tendency to dilate when compared to poorly-graded soils. Sitharam et al. (2009) showed that the post-liquefaction strain-hardening response was affected by the amplitude of the strain accumulated during cyclic loading, where higher accumulated strains delayed the start of the dilative response. Dash (2010) introduced the concept of take-off shear strain to denote the strain level required to mobilise $1 \mathrm{kPa}$ shear strength. Lombardi \& Bhattachrya (2014) proposed a bi-linear stress-strain model to replicate the post-liquefaction behaviour observed in laboratory tests, which was later adopted for the construction of $p-y$ curves for liquefied soils (Lombardi et al., 2017). The research carried so far has conclusively shown that the post-liquefaction behaviour of liquefied soils is strongly dependent on the tendency of the liquefied soil to dilate, which in turn depends on its initial state (ie, dilative or contractive), and accumulated cyclic strain.

Traditionally, the state of a soil has been expressed by in-situ parameters, such as the void ratio or relative density. However, the latter have erroneously been treated as 'true' properties of the material rather than state variables (Jefferies \& Been, 2015). Consequently, the majority of the available proce- 
dures for the assessment of liquefaction susceptibility and post-liquefaction behaviour treat the different states in which a soil can be found as if it were different materials rather a single material found at different states. To overcome this inconsistency, we propose a state-dependent procedure determine the post-cyclic deformation of liquefied sloping grounds.

The main advantage of using a state-dependent approach is to model adequately the dependency of the soil response to its stress state. Furthermore, as the proposed approach predicts the level of deformation attained by the liquefied soil after the shaking, rather than its residual strength or factor of safety, the method provides residual deformation estimates that can be used to define the performance criteria for different levels of displacements (see capacity curve in Figure 2) in accordance with displacement-performance-based design approaches used in routine practice Bhattacharya et al. (2019).

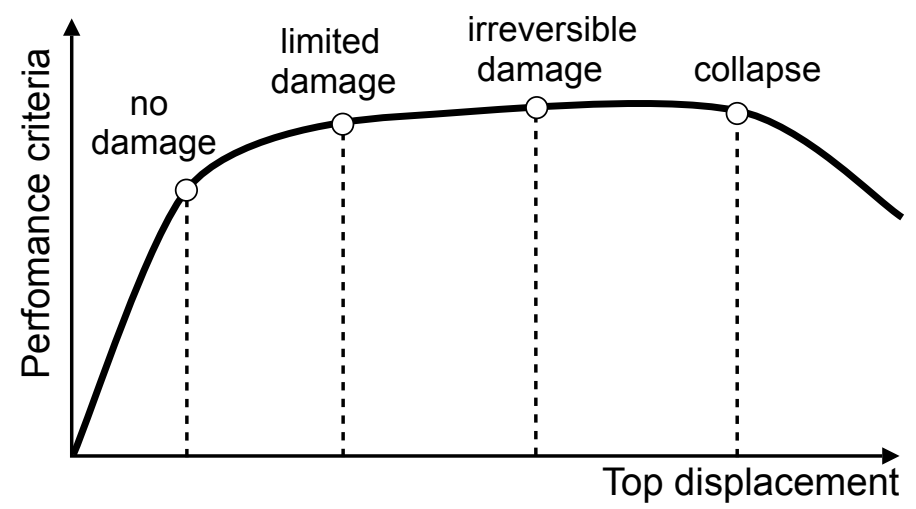

Figure 2: Capacity curve for definition of performance criteria

The proposed method involves four steps: i) determine critical state parameters of the soil from reconstituted soil samples; ii) determine liquefaction and post-liquefaction behaviour using multi-stage triaxial tests on representative samples, or empirical relationships; iii) compute take-off shear strain of 
Table 1: Index properties of Redhill 110

\begin{tabular}{|c|c|c|c|c|c|c|}
\hline Material & $G_{s}$ & $e_{\max }$ & $e_{\min }$ & $D_{50}$ & $U_{c}$ & \\
\hline Redhill 110 & 2.65 & 1.04 & 0.61 & 0.14 & 1.63 & \\
\hline
\end{tabular}

liquefied soil, defined as the strain level beyond which the liquefied soil develops increasing strength and stiffness upon shearing; iv) compute instability curves.

The application of the four steps is presented in detail in the following sections with reference to a highly-susceptible fine silica sand. Although the method has general validity and applicability, the instability curves need to be calibrated from representative soil samples before being used for soils different from that used in this work. However, in the absence of the latter, the proposed relationships can still be used for preliminary design and decision making considerations. Finally, the practical application of the instability curves is illustrated a real case study.

\section{Testing material}

The testing material consisted of a poorly-graded, fine-grained silica sand, commercially available by the name Redhill 110 . This specific sand was chosen because of its high susceptibility to liquefaction (see particle size distribution and liquefaction-prone bounds in Figure 3) and use in previous liquefaction studies (see Lombardi \& Bhattachrya, 2014; Lombardi et al., 2014; Lombardi \& Bhattachrya, 2016; Lombardi et al., 2017). The index properties of Redhill 110 are listed in Table 1. 


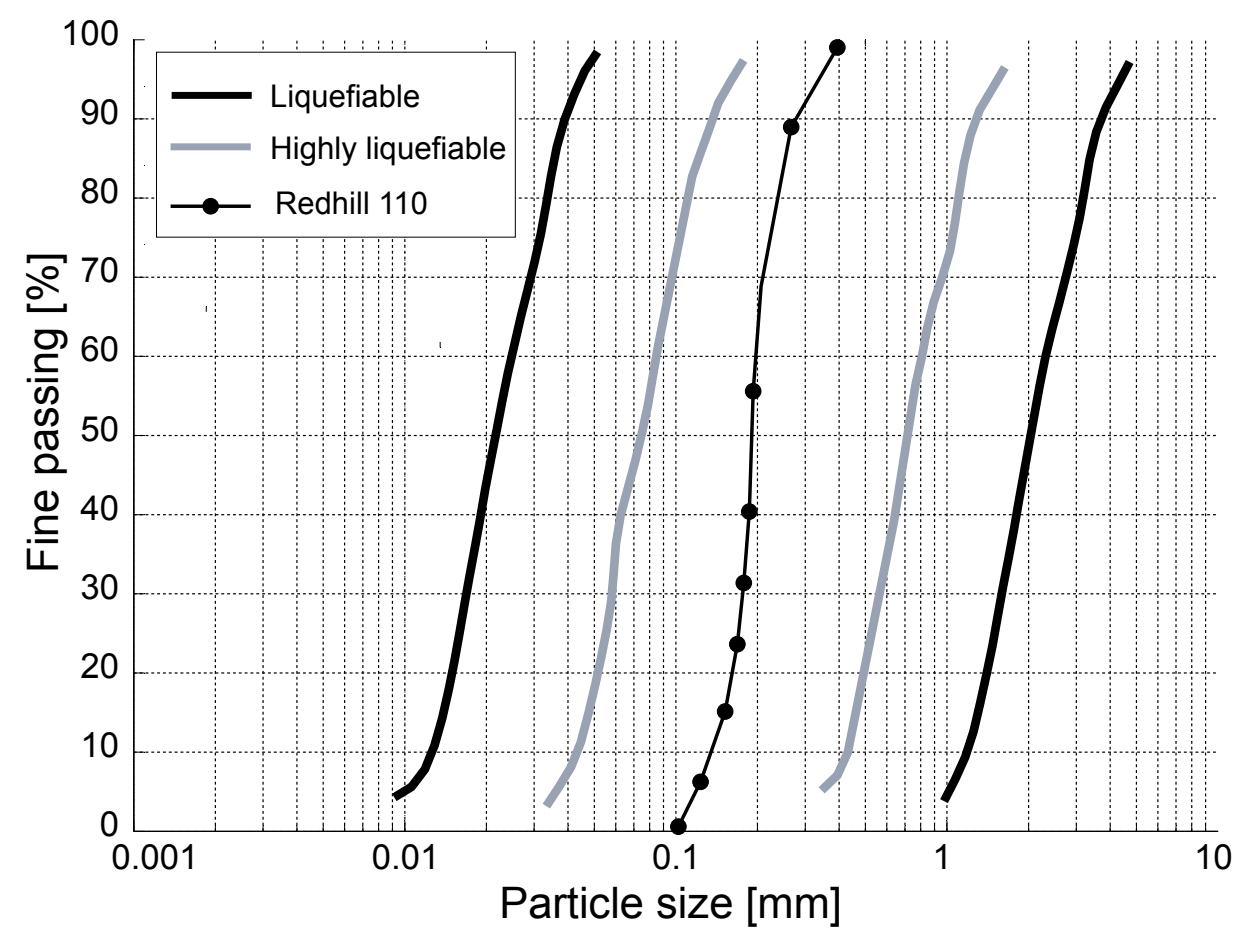

Figure 3: Particle size distribution of Redhill 110 sand, and liquefiable and highly liquefiable prone bounds

\section{Step 1: Critical state parameters}

At the critical state a unique combination of effective stress ratio $M_{c}$ and void ratio $e_{c}$ exists, whose variations with stress are given by equations 1 and

2. These are also graphically shown in Figure 4.

$$
\begin{gathered}
M_{c}=\frac{q}{p^{\prime}} \\
e_{c}=e_{0}-\lambda\left(\frac{p^{\prime}}{p_{a}}\right)^{\xi}
\end{gathered}
$$

where $M_{c}, \lambda$, and $\xi$ are intrinsic soil properties, $e_{0}$ is the void ratio at a reference stress, taken equal to $1 \mathrm{kPa}$ by convention; $p_{a}=101 \mathrm{kPa}$ is the 


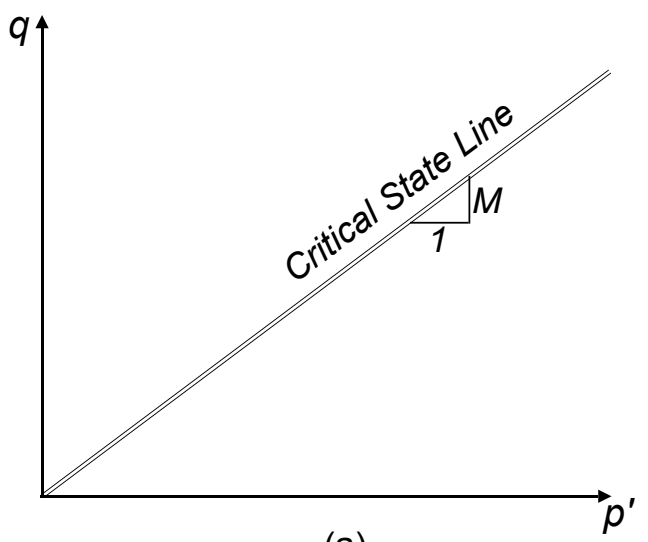

(a)

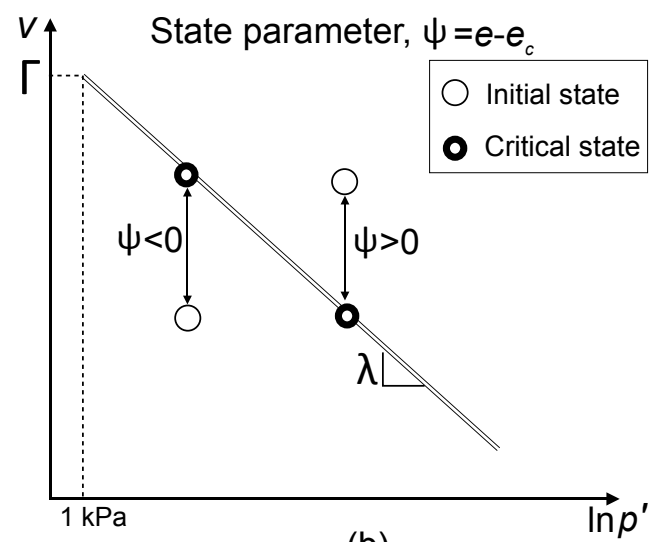

(b)

Figure 4: Definition of critical state parameters: $M_{c}, \lambda$ and $\Gamma$, and state parameter $\psi$ in (a) deviator stress $q$ vs. mean effective stress $p^{\prime}$; (b) specific volume $v$ vs. natural logarithm of mean effective stress $\ln p^{\prime}$.

atmospheric pressure used for normalisation; the deviator stress $q$ is derived from the second invariant of the stress tensor; the mean effective stress $p^{\prime}$ denotes the first invariant of the stress tensor. In the triaxial space $\left(\sigma_{1}^{\prime}>\right.$ $\left.\sigma_{3}^{\prime}=\sigma_{2}^{\prime}\right)$ these invariants can be expressed as follows

$$
\begin{gathered}
q=\sigma_{1}^{\prime}-\sigma_{3}^{\prime} \\
p^{\prime}=\frac{\sigma_{1}^{\prime}+2 \sigma_{3}^{\prime}}{3}
\end{gathered}
$$

It is worth noting that although equation 2 differs from the original linear relation $e_{c}=\Gamma-\lambda \ln \left(p^{\prime}\right)$ by (Schofield \& Wroth, 1968), the power law in equation 2 by Li \& Wang (1998) has been increasingly used by researchers and adopted in constitutive modelling of sands (Dafalias \& Manzari, 2004), hence it is used in the present study. The proximity of the initial state to its corresponding critical state is quantified by means of the state parameter, $\psi$, defined as the difference between initial void ratio and its corresponding value at the critical state at the same stress level (Been \& Jefferies, 1985). From its 
definition, it follows that positive and negative state parameters correspond to contractive and dilative soils, respectively. The graphical definition of $\psi$ is depicted in Figure 4.

$$
\psi=e-e_{c}
$$

It is noted that although the uniqueness the critical state parameters for a given soil is widely accepted, effects due to strain localisation (eg, formation of shear bands in triaxial compression, and necking in triaxial extension) and fabric anisotropy may result in these parameters being dependent on the stress path, instrumentation (eg, local strain measurements, etc.) and type of tests adopted for their derivations (see Desrues et al., 1996; Salvatore et al., 2017). Yet such effects are not explicitly considered in the present work, and the critical parameters are herein inferred using a macroscopic phenomenological approach based on global measurements of strain and stress.

The critical state parameters were estimated from four strain-controlled drained triaxial tests (see Table 2). The samples were isotropically consolidated at four different confining stresses, and then sheared at constant mean effective stress while the drained conditions allowed the void ratio and deviator stress to change and bring the material to its critical state. The change in void ratio of the sample was determined from measurements of axial displacements recorded by LVDTs; stresses were computed based on measurements from a load-cell placed inside the triaxial cell between the upper pedestal and the piston. Furthermore correction factors for the effects of membrane penetration and cross-sectional area changes were automatically considered 
during the test for an accurate derivation of test parameters.

The specimens were prepared by pluviating dry sand through a cone shaped funnel into the sample-forming mould. The final dimensions of the samples were approximately $50 \mathrm{~mm}$ in diameter and $100 \mathrm{~mm}$ in height. The density of each specimen was controlled by varying the height of fall and diameter of the nozzle, although for denser samples, a wooden mallet was used to obtain a higher degree of packing. Full saturation, defined by a B-value greater than 0.96 , was achieved by percolating carbon dioxide through the sample, which was successively displaced by de-aired water before applying a back-pressure of $200 \mathrm{kPa}$ for $24 \mathrm{~h}$. To minimise effects due to friction, the end-platens were lubricated with silicon grease.

Table 2: Test summary: monotonic drained tests for derivation of critical state parameters

\begin{tabular}{l|l|l|l|l}
\hline Test ID & $\sigma_{3}^{\prime}[\mathrm{kPa}]$ & $e$ & $\epsilon_{D A}[\%]$ & $\psi$ \\
\hline MO-1 & 100 & 0.870 & - & -0.060 \\
MO-2 & 500 & 0.859 & - & -0.034 \\
MO-3 & 1000 & 0.825 & - & -0.035 \\
MO-4 & 1400 & 0.807 & - & -0.030 \\
\hline
\end{tabular}

Figure 5 shows the stress path in the $q-p^{\prime}$ space, and the evolution of the void ratio in the normalised space $e-\left(p^{\prime} / p_{a}\right)^{0.7}$. Because of the shearing under constant $p^{\prime}$, the trace of each test in both spaces is vertical. During the test the void ratio and deviator stress changed to bring the material into its critical state condition, at which no further changes in void and stress ratio occurred (see Figure 6). 

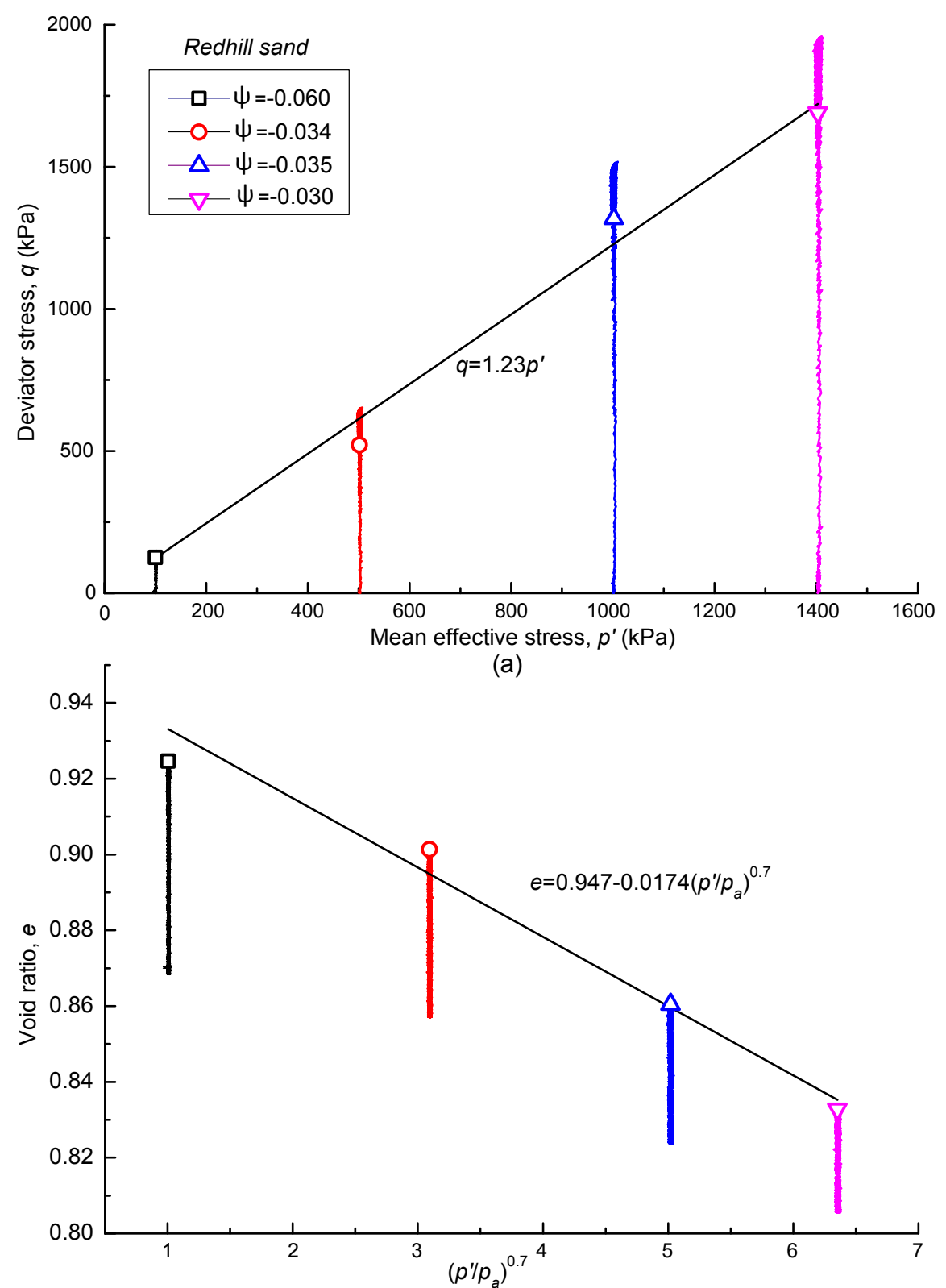

(b)

Figure 5: Results from drained monotonic tests used for derivation of relevant critical state parameters: (a) stress path and critical state line in $q-p^{\prime}$ plot; (b) variation of void ratio and critical state line in normalised $e-\left(p^{\prime} / p_{a}\right)^{0.7}$ plot. 


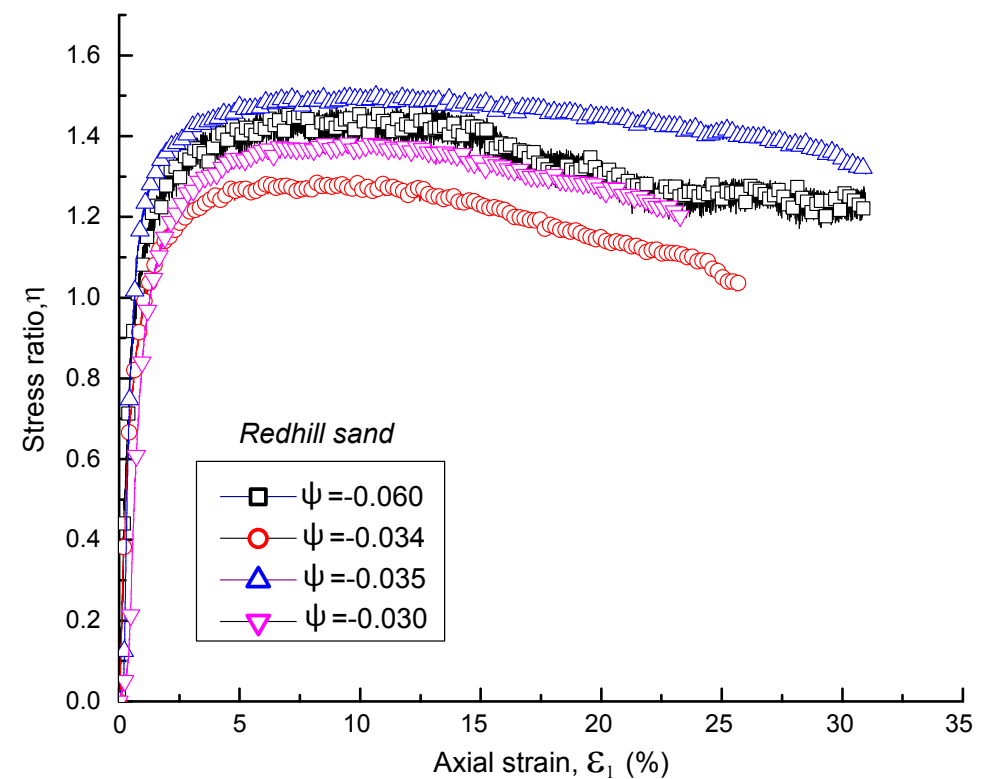

(a)

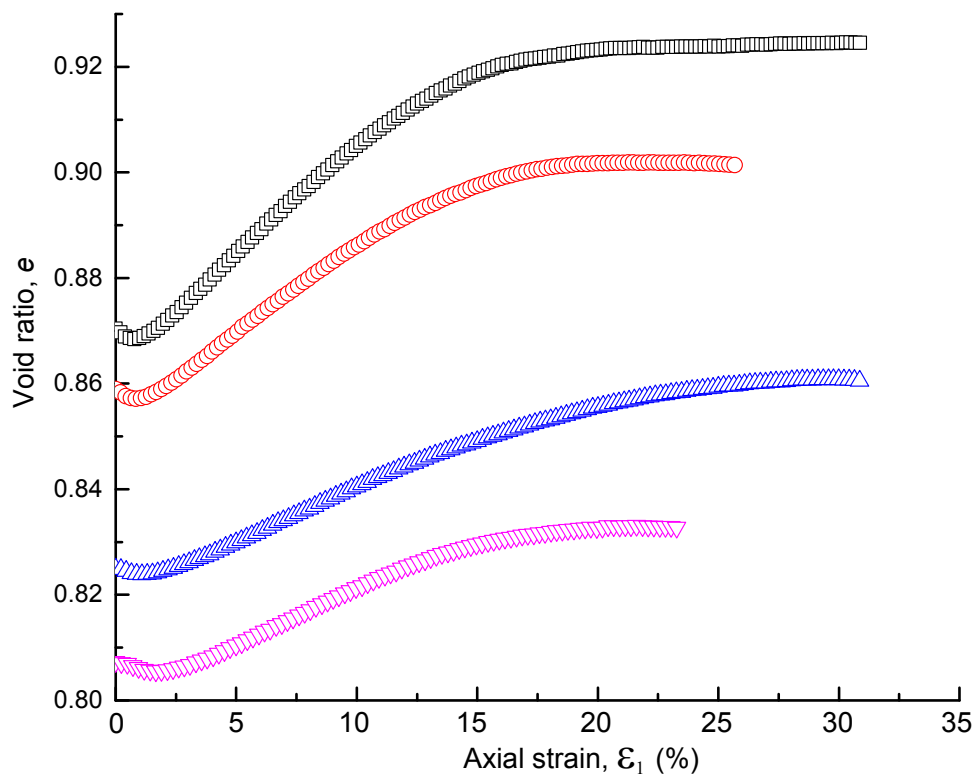

(b)

Figure 6: Results from drained monotonic tests: (a) stress ratio $\eta$ vs axial strain $\epsilon_{1}$; (b) void ratio $e$ vs. axial strain $\epsilon_{1}$.

The post-peak strain softening behaviour observed in the stress-strain responses plotted in Figure 6 was attributed to the formation of shear bands, 
which are known to cause strain concentration and consequent reduction in void ratio in a narrow zone close to the shear planes. Despite the formation of shear bands, it can be seen that -after an initial contraction, all samples dilated and reached an ultimate value of void ratio that remained practically constant during shearing at strain up to $20 \%$. The ultimate states attained by the samples were fitted with a linear function, whose coefficients provided the sought critical state parameters.

\section{Step 2: Liquefaction and Post-liquefaction response}

Multi-stage (cyclic+monotonic) triaxial tests were carried to determine the liquefaction and post-liquefaction responses of the testing material. Specimens were prepared at different initial void ratios following the preparation method described in the previous section. It is noted that, as it is uncommon to find naturally-deposited soils at a state looser than critical, ie, above the SSL in Figure $1(\psi>0)$, samples were prepared at void ratios and subjected to confining stresses $\sigma_{3}^{\prime}$ that resulted in initial states denser than critical, ie, below the SSI $(\psi<0)$. To investigate the liquefaction and post-liquefaction response, a multi-stage loading was adopted whereby samples were first liquefied by means of a cyclic sinusoidal waveform applied at a constant frequency of $0.1 \mathrm{~Hz}$, and then subjected to monotonic shearing without dissipation of excess pore-water pressure between the two loading stages (see Figure 7). 


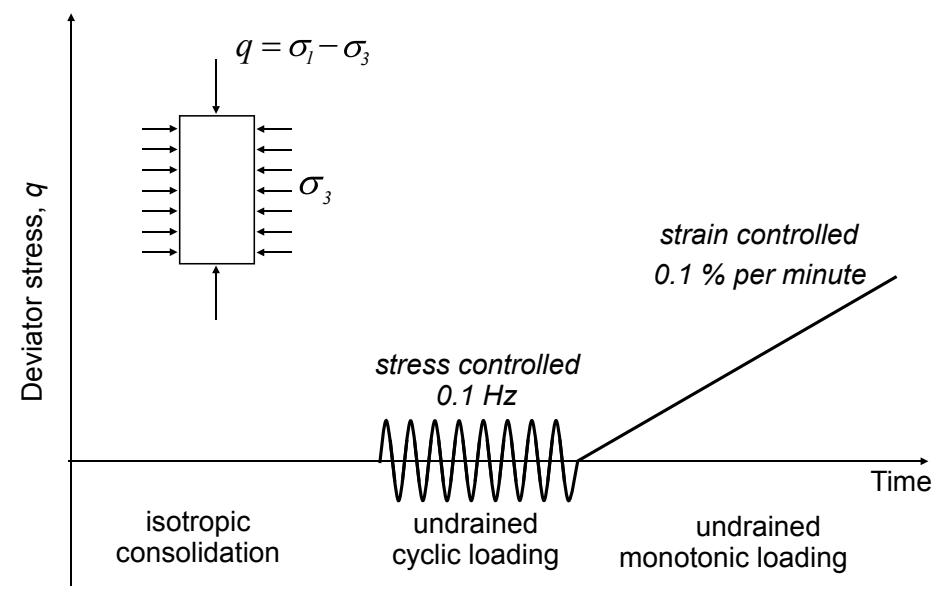

Figure 7: Schematic representation of loading path applied in undrained multi-stage triaxial tests.

As the samples were dilative, the onset of liquefaction, or more specifically cyclic mobility, was defined as the condition whereby the soil developed a predefined value of double-amplitude (DA) axial strain, $\epsilon_{D A}$, which is usually taken equal to $\epsilon_{D A}=5 \%$ after (Ishihara, 1993). However, higher values of $\epsilon_{D A}(7.5 \%, 10 \%$ and $12.5 \%)$ were also considered to investigate their effects on the post-liquefaction behaviour. A summary of the test conditions is summarised in Table 3.

\subsection{Cyclic response}

The response of sand to undrained cyclic loading has been extensively investigated and reported in the literature (Ishihara, 1993), thus it is only briefly discussed herein. Typical results obtained from samples prepared at different initial states and representing those of marginally dilative (test ID: MU-1) and highly dilative sands (test ID: MU-11), are illustrated in Figure 8. The stress-strain responses exhibited hysteresis loops that gradually increased in 
Table 3: Test summary: undrained multi-stage triaxial tests for derivation of instability curves

\begin{tabular}{l|l|l|l|l}
\hline Test ID & $\sigma_{3}^{\prime}[\mathrm{kPa}]$ & $e$ & $\epsilon_{D A}[\%]$ & $\psi$ \\
\hline MU-1 & 100 & 0.915 & 5 & -0.015 \\
MU-2 & 100 & 0.856 & 5 & -0.074 \\
MU-3 & 100 & 0.830 & 5 & -0.100 \\
MU-4 & 100 & 0.783 & 5 & -0.147 \\
MU-5 & 100 & 0.728 & 5 & -0.202 \\
MU-6 & 100 & 0.702 & 5 & -0.228 \\
MU-7 & 100 & 0.903 & 7.5 & -0.027 \\
MU-8 & 100 & 0.898 & 10 & -0.032 \\
MU-9 & 100 & 0.898 & 12.5 & -0.032 \\
MU-10 & 100 & 0.770 & 7.5 & -0.160 \\
MU-11 & 100 & 0.775 & 10 & -0.155 \\
MU-12 & 100 & 0.766 & 12.5 & -0.164 \\
\hline
\end{tabular}

size owing to increasing damping and reduction in effective stress. The latter was caused by a progressive rise of excess pore pressure, quantified by the excess pore pressure ratio, $r_{u}=\Delta u / \sigma_{3}^{\prime}$.

The stress paths in Figure 8 show that both samples showed a tendency to contract under cyclic loading despite being initially dilative with negative $\psi$ (see Table 3). From the figure, it can be seen that the stress paths progressively moved to the left in the direction of decreasing effective stress, forming the characteristic 'butterfly' shape as the stress approached zero. 


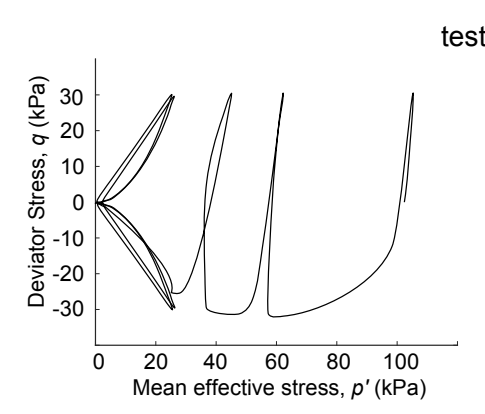

test ID: MU-1
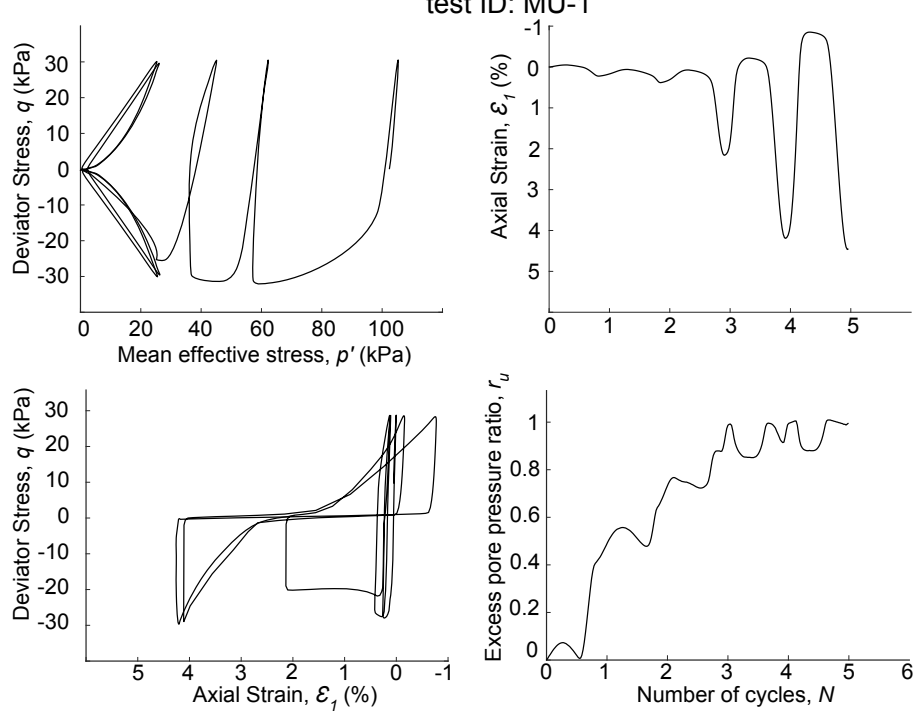

test ID: MU-11
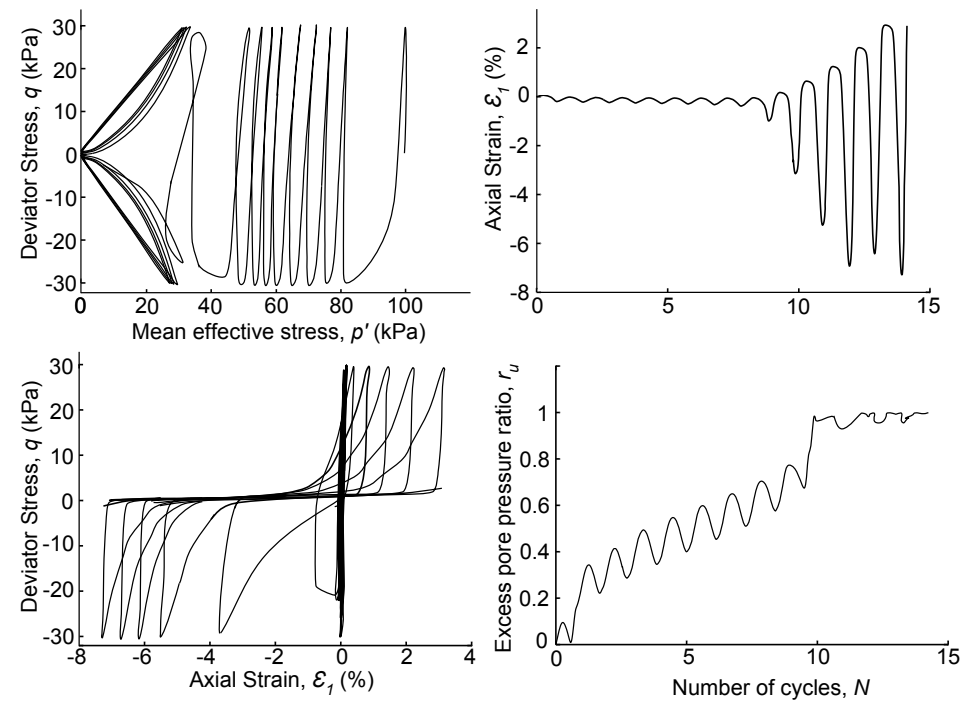

Figure 8: Results from cyclic loading from undrained multi-stage tests: (a) test ID: MU-1 ; test ID: MU-11.

\subsection{Post-liquefaction monotonic response}

Figure 9 shows the results undrained monotonic tests, and compares the stress-strain responses of samples prepared at different initial states, but cyclically sheared to the same $\epsilon_{D A}$ (ie, $5 \%$ ). As expected highly dilative 
1 samples (ie, $\psi<<0$ ) showed a greater tendency to dilate, resulting in the 2 soil to develop a strain-hardening response at relatively low strain levels when compared to marginally dilative samples $(\psi<0)$.
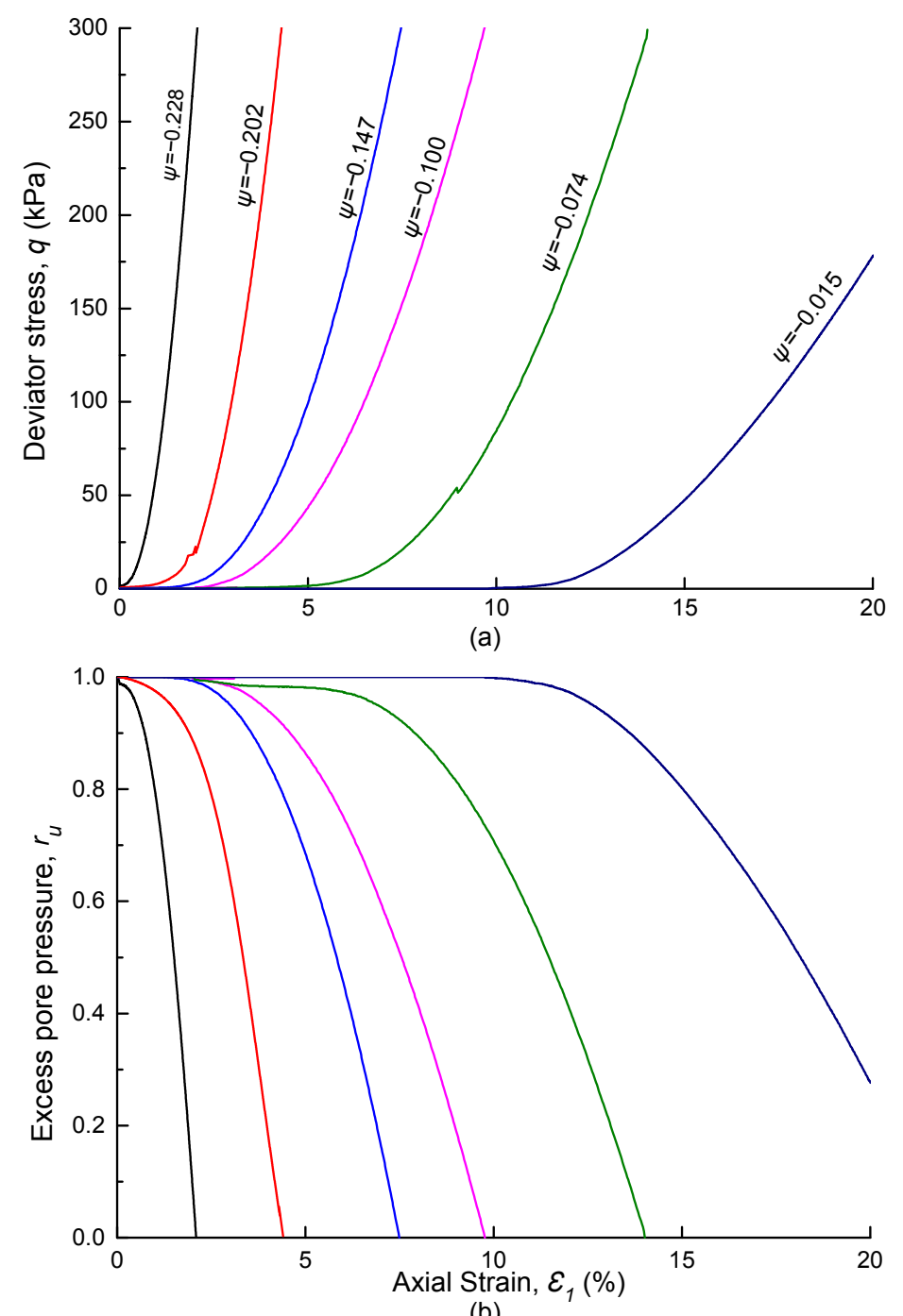

(b)

Figure 9: Results from undrained monotonic tests on liquefied samples at different $\psi$ and constant $\epsilon_{D A}=5 \%$ : (a) deviator stress $q$ vs. axial strain $\epsilon_{1}$; (b) excess pore pressure $r_{u}$ vs. axial strain $\epsilon_{1}$.

The definition of maximum strength in these tests is erroneous since its value depends on the maximum negative excess pore pressure that the sample 
can develop before reaching cavitation; thus the maximum stress attained by the samples should not be interpreted as the post-liquefaction strength of the material.

The monotonic undrained test results carried out on liquefied samples for two ranges $\psi$, representing highly dilative and marginally dilative soil, but sheared at different accumulated $\epsilon_{D A}$ are shown in Figure 10. The effect of the accumulated $\epsilon_{D A}$ on the post-liquefaction is clear, showing a delayed dilation at larger $\epsilon_{D A}$.
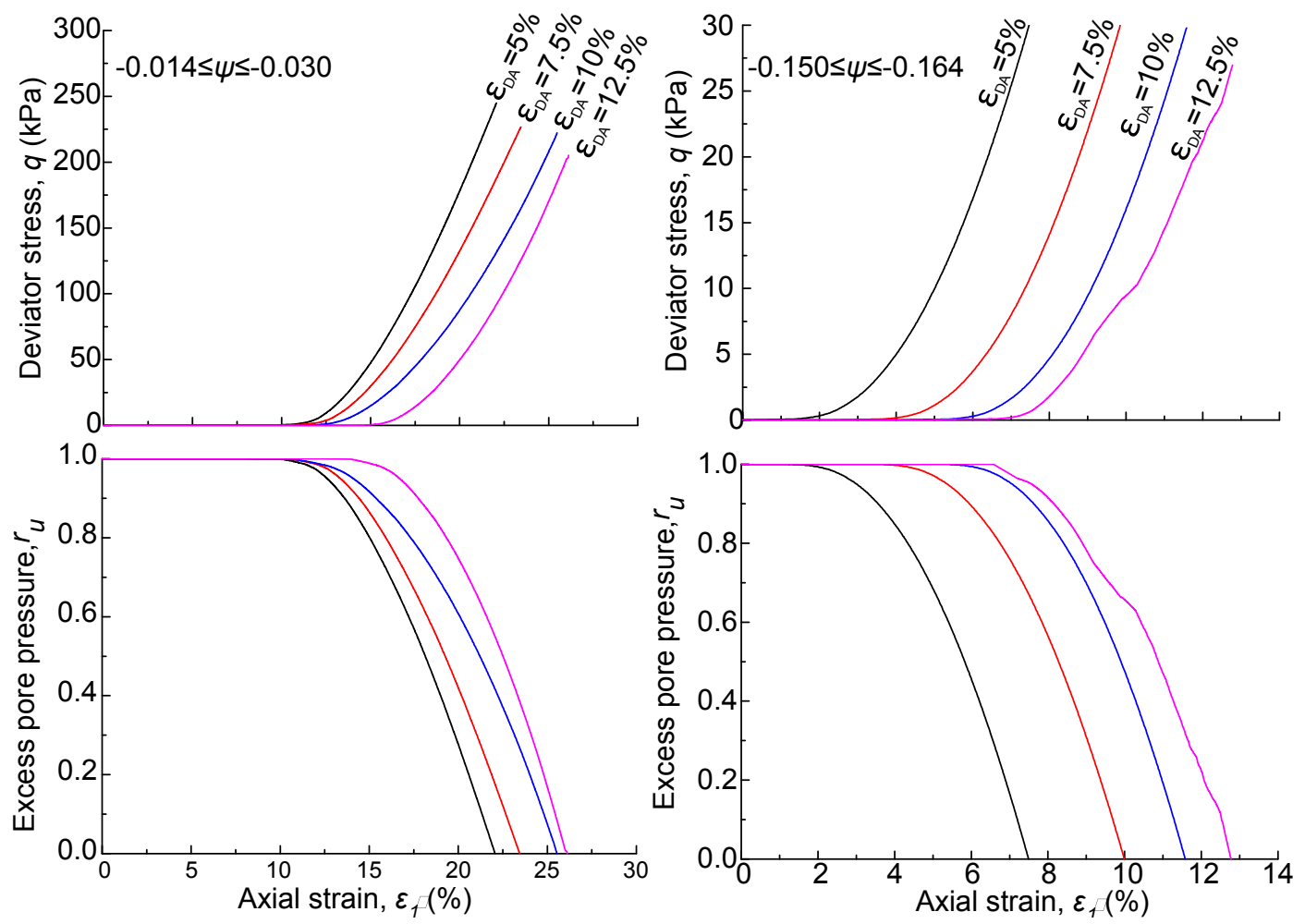

Figure 10: Results from undrained monotonic tests carried out on liquefied samples at two ranges of $\psi$ and different accumulated double amplitude cyclic strain $\epsilon_{D A}$. 


\section{Step 3: Take-off shear strain, $\gamma_{t o}$}

The dilative response, and consequent strain-hardening behaviour is quantified by means of the take-off strain, $\gamma_{t o}$, defined by Dash (2010) as the engineering strain required by the liquefied soil to mobilise $1 \mathrm{kPa}$ shear stress (see inset in Figure 11). Once the soil is sheared beyond $\gamma_{t o}$ the strength progressively increases upon shearing. The computed values of $\gamma_{t o}$ are shown in Figure 11. It can be seen that $\gamma_{\text {to }}$ grows exponentially with decreasing $\psi$ (see top plot in Figure 11), with values ranging from $<0.1 \%$ for highly dilative samples to values as high as $20 \%$ for marginally dilative samples. It can be concluded that in highly dilative samples (ie, $\psi<-0.15$ ) the liquefied soil immediately exhibit a strain-hardening behaviour $\left(\gamma_{t o}<5 \%\right)$ with strength and stiffness increasing upon monotonic shearing, while in the in the marginally dilative soils such an increase starts at strains $\gamma_{t o}>10 \%$ ) .

The effect of the accumulated cyclic strain on the post-liquefaction behaviour is investigated by introducing a normalised take-off shear strain $\gamma_{t o} / \gamma_{t o-5 \%}$, in which the $\gamma_{t o}$ is normalised by the corresponding take-off shear strain of a sample with same $\psi$ but cyclically sheared up to $5 \%$. From Figure 11, it can be seen that the normalised take-off shear strain increases linearly with increasing $\epsilon_{D A}$, suggesting that the level of deformation accumulated during the application of cyclic load shift the start of the strain-hardening behaviour at greater strains. 


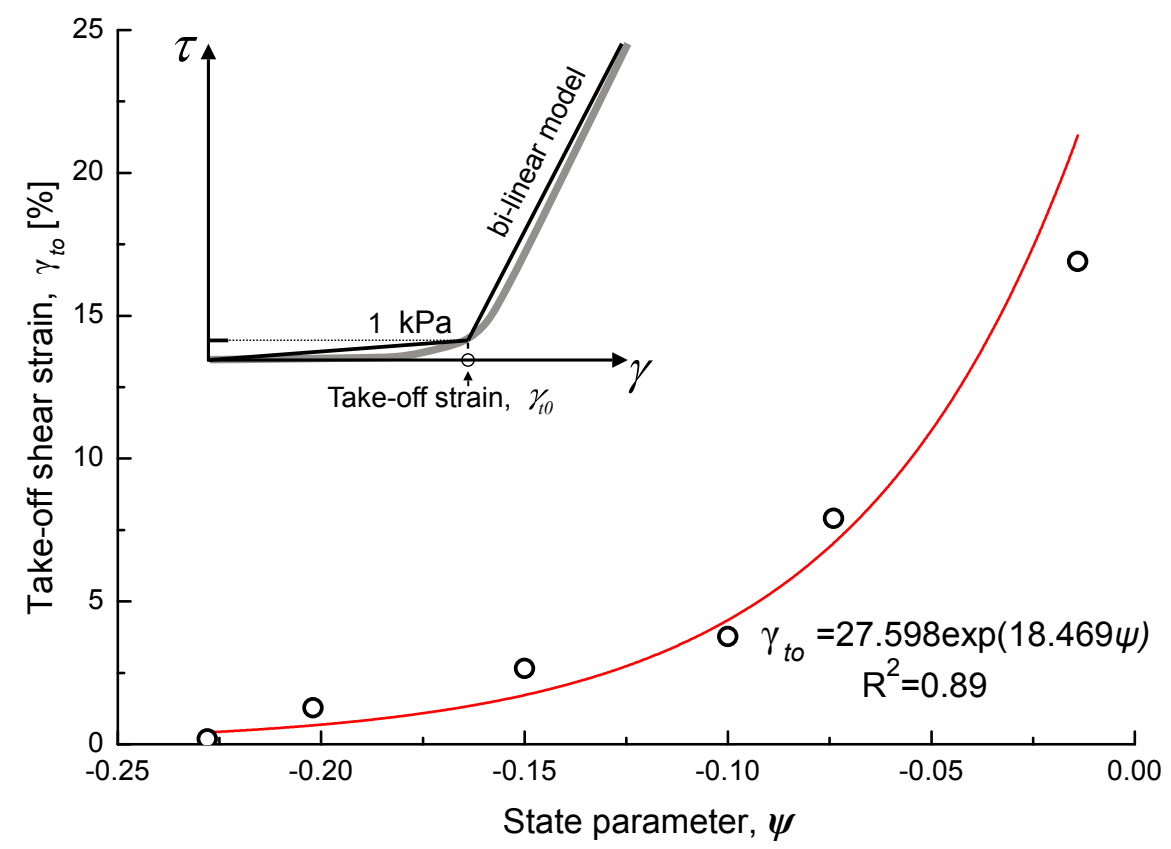

(a)

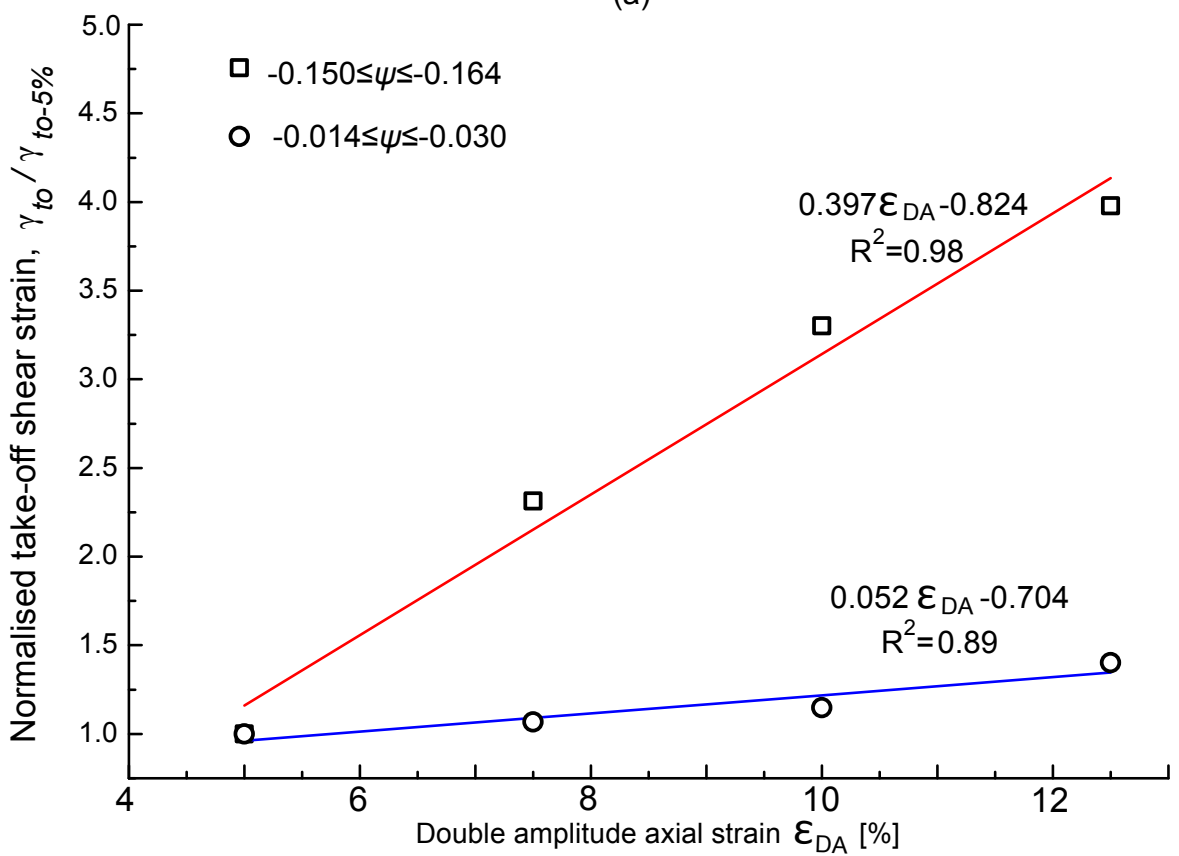

(b)

Figure 11: Effect of state parameter and accumulated cyclic double amplitude strain on: take-off shear strain -the latter is graphically defined in the inset: (a) $\gamma_{t o}$ vs $\psi$; (b) $\gamma_{t o}$ vs. $\epsilon_{D A}$ 


\section{Step 4: Instability curves}

A family of curves can be introduced to define the level of strain that the liquefied soil has to mobilise before regaining strength and stiffness, and developing the characteristic strain-hardening behaviour observed in the element tests described earlier (see Figures 9 and 10). Such curves are thus named instability curves and are shown in Figure 12. According to the proposed definition, the area below each curve represents states in which the liquefied soil has practically zero strength and stiffness, and it is thus highly unstable due to its tendency to develop large deformations. By contrast, the area above each curve represents states of the liquefied soil where the strain-hardening behaviour is already developed, thus representing a stable condition since the soil gradually increases strength and stiffness upon shearing.

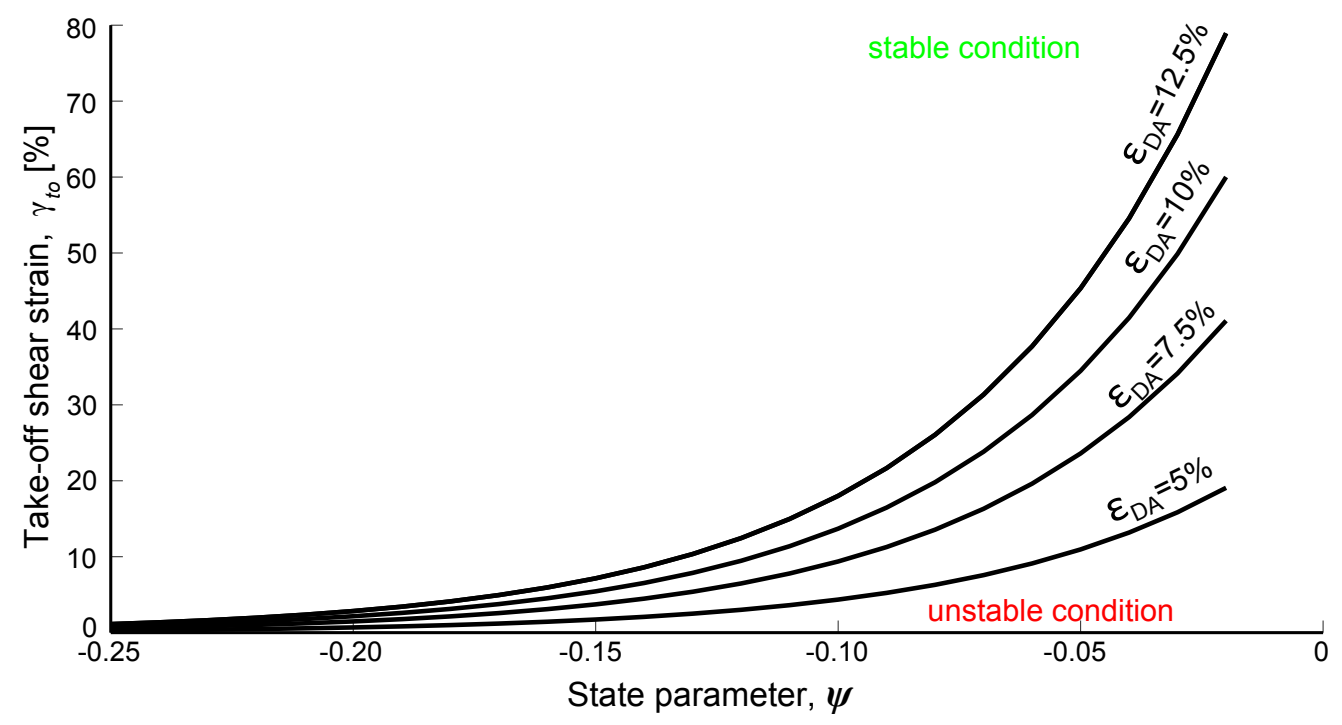

Figure 12: Post-cyclic instability curves for liquefied sand.

The instability curves can be computed from state parameter and accu- 
1 mulated cyclic strain. The state parameter can be conveniently determined 2 based on semi-empirical relationships from CPT data (see Figure 13). The value of accumulated cyclic strain $\epsilon_{D A}$ depends on the duration and severity of the earthquake, where longer and stronger shaking are likely to induce larger $\epsilon_{D A}$.

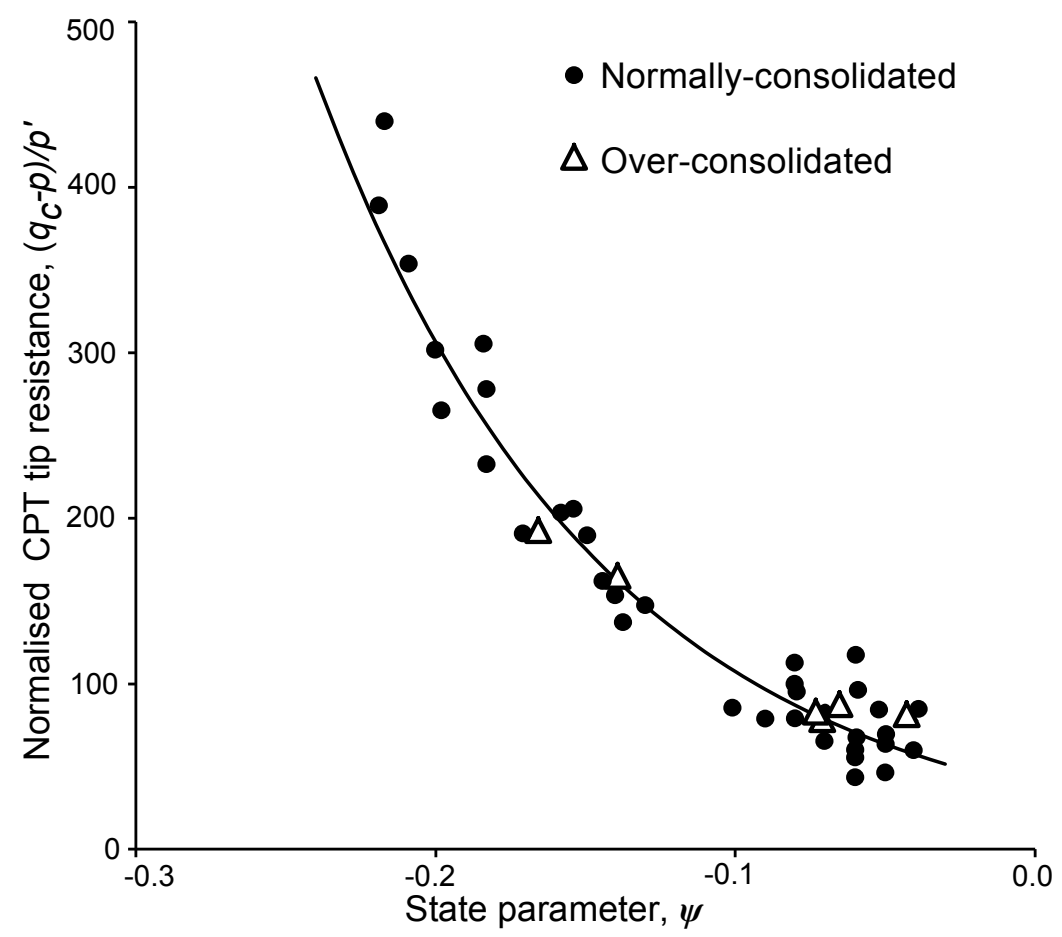

Figure 13: Normalised CPT resistance $q_{c}$ vs. state parameter $\psi$, after Jefferies \& Been (2015).

\section{Application of instability curves to Lower San Fernando Dam}

The use of the instability curves is demonstrated through the back-analysis of the liquefaction failure of the Lower San Fernando Dam observed after the 
1971 earthquake. The failure involved the collapse of the top 9m of the upstream side, which occurred a minute after the end of the shaking. Although catastrophic consequences were averted by drawing down the reservoir before the dam failed completely, about 80,000 people that leaved in a 6 mile long area downstream were evacuated.

The failure of the Lower San Fernando Dam represents a typical example of post-liquefaction induced slide, thus serving as an ideal case to demonstrate the use of the proposed instability curves.

The San Fernando Dam was built using the hydraulic fill method, which involved discharging the construction material along the upstream and downstream shores of the reservoir. The protective shells on both side of the dam were formed by the coarser material that deposited quickly under water, whereas the finer material was transported toward the centre, where it formed the impermeable core of the dam.

The Lower San Fernando Dam was extensively investigated after the failure and a report by Seed et al. (1988) provided the pre- and post-failure geometries shown in Figure 14. 

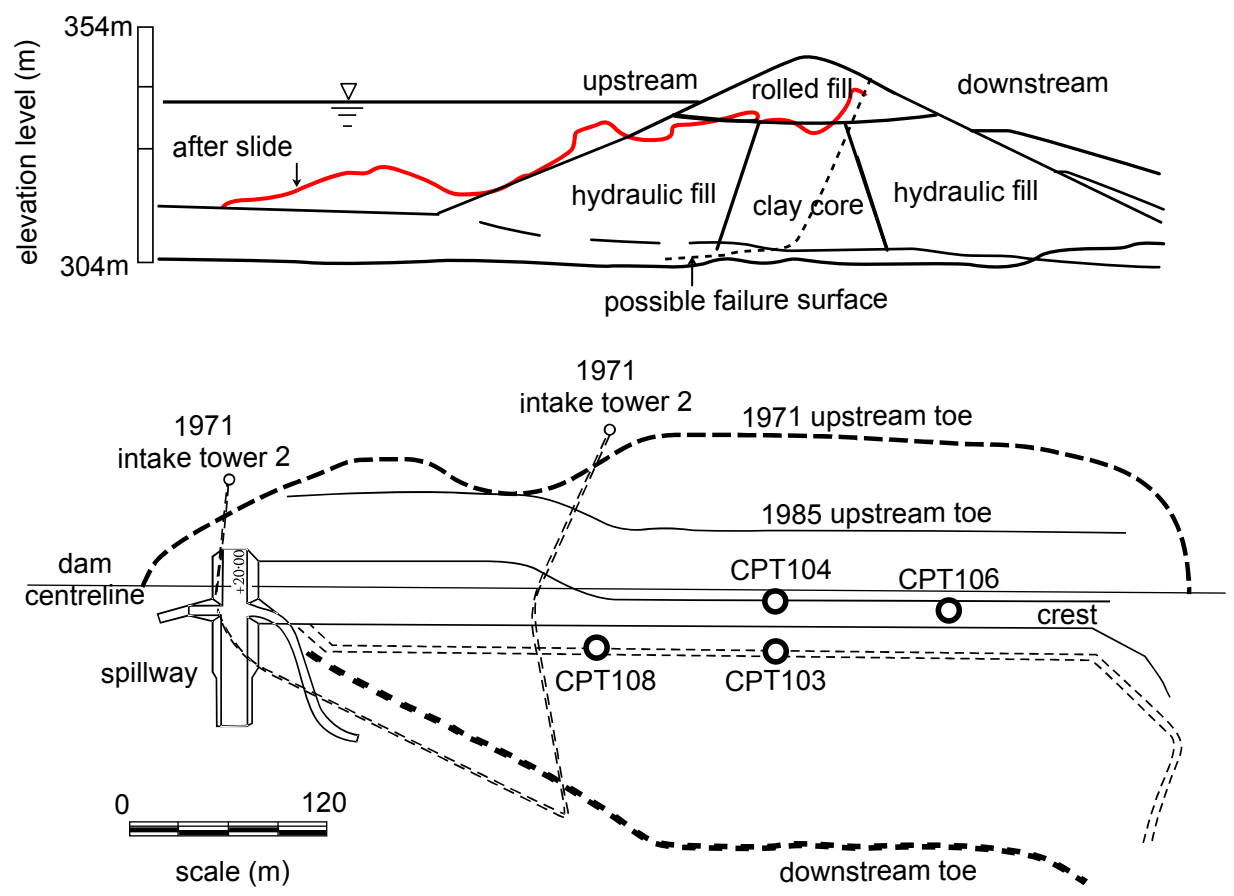

Figure 14: Lower San Fernando Dam: (top) cross-section of dam before and after failure. (bottom) plan view of dam and locations of CPT profiles. Modified from Seed et al. (1988) and Castro et al. (1992).

Although the dam was rebuilt in 1975 , further site investigations were carried out in 1985, which included CPT tests at the locations shown in Figure 14. The CPT data was used by Jefferies \& Been (2015) to determine profiles with depth of the state parameter, and its characteristic value $\psi_{k}$ corresponding to the 90 -percentile. As it can be seen from Figure 15, the state parameter was found to vary depending on the soil gradation and densities. In particular, the peaks and troughs of the $\psi$ profile represented loose and denser layers, respectively. The characteristic value $\psi_{k}$ for the coarser material forming the shells of the dam varied considerably between the upstream $\left(-0.12<\psi_{k}<-0.11\right)$ and downstream $\left(-0.03<\psi_{k}<0.09\right)$. 


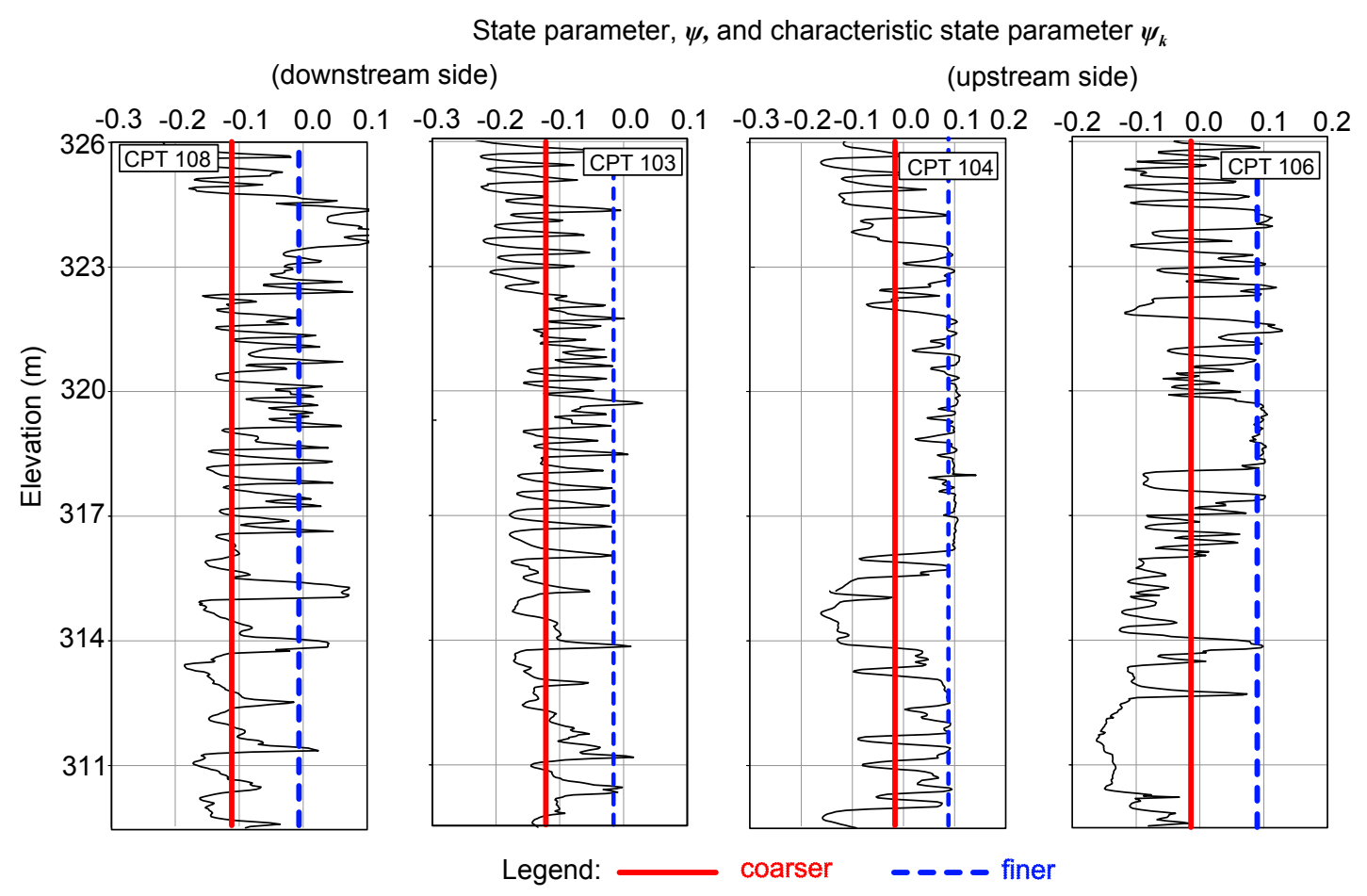

Figure 15: State parameter profiles with depth after Jefferies \& Been (2015). CPT locations shown in Figure 14

Figure 16 shows the distribution of $\psi_{k}$ within the slope, and the corresponding take-off shear strain determined from the instability curves of Figure 12 or the equation in Figure 11. It should be noted that in the absence of detailed information or analysis, the instability curves should be used for an $\epsilon_{D A}$ of $5 \%$, which, as mentioned earlier, corresponds to the value typically taken to define the onset of liquefaction. It can be seen that the distribution of strain is consistent with the damage pattern also shown in Figure 16, in which the upstream shell exhibits considerably larger movements than that of the downstream side.

Finally, the shear strain distribution can be used to compute an approxi- 
mate value of maximum horizontal displacement using the method of Seed et al. (1973). This approach assumes that the maximum shear stress act along the horizontal planes and result in a top displacement equal to the product of the average shear strain and the height of the section. According to the strain distribution shown in Figure 16, the maximum horizontal displacement at the crest of about $3.8 \mathrm{~m}$. This estimate agrees well with range of displacements recorded after the failure and reported in the literature (Seed et al., 1988).
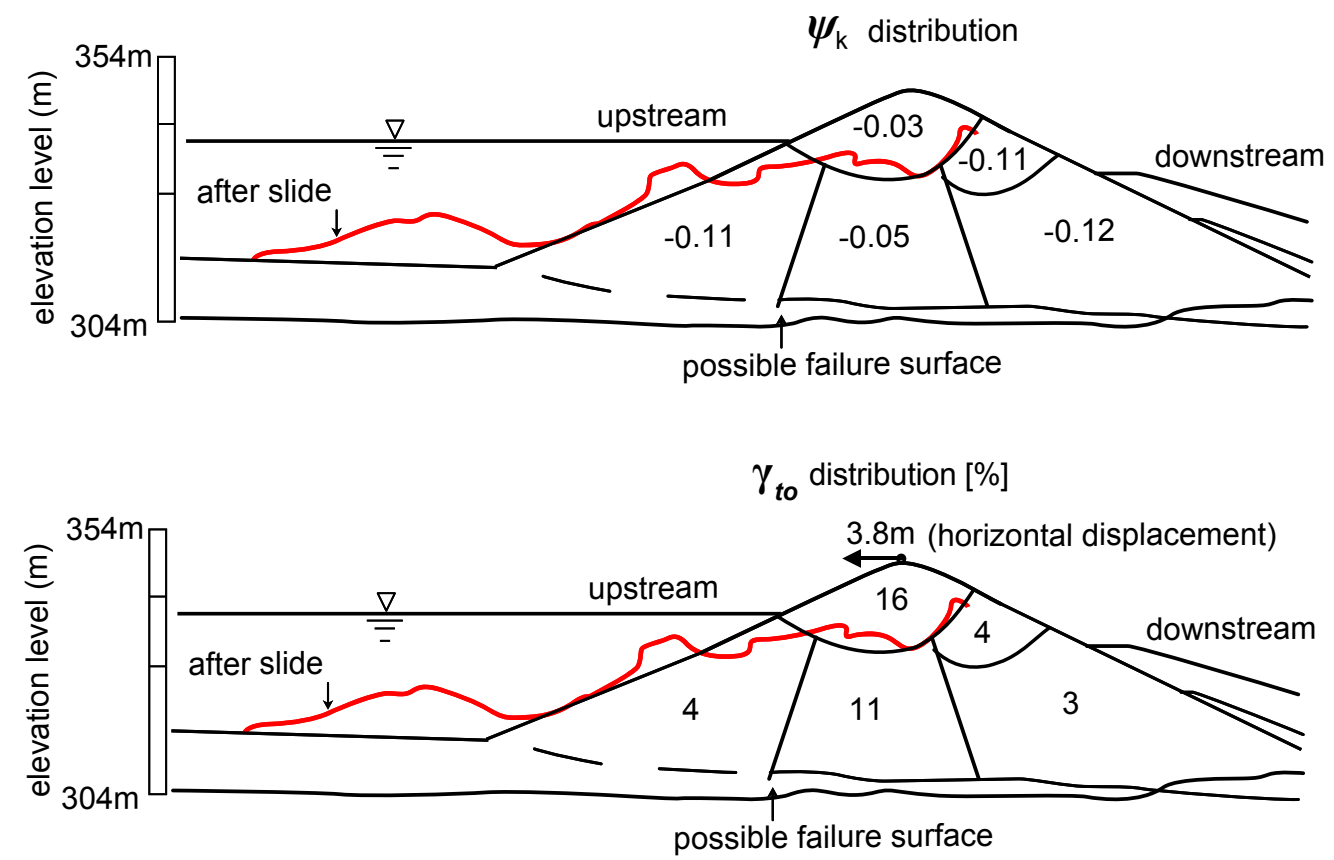

Figure 16: Application of instability curves: (Top) Approximate distribution of characteristic value of state parameter $\psi_{k}$. (Bottom): computed take-off shear strain distribution $\gamma_{t o}$ and maximum horizontal displacement at crest 


\section{Conclusion}

This paper introduces a state-dependent approach for the assessment of postcyclic deformation of liquefied sloping grounds that is consistent with displacement performance-based design approaches used in routine practice. It is demonstrated that the salient aspects governing the post-liquefaction behaviour can be taken into account by means of a single state parameter: the state parameter, $\psi$, defined as void ratio difference between current and critical state. The proposed approach provides a unified method for the analysis of post-liquefaction performance of soil masses, with the advantage of being dimensionless and stress-level independent. A set of instability curves are finally introduced to identify the level of deformation required by the liquefied soil to develop the characteristic strain-hardening behaviour. The curves define a limiting condition below which the liquefied soil deforms at practically zero strength and stiffness. This represents a highly unstable condition that may lead to significant damage in real earthworks. It is finally argued that the proposed post-liquefaction stability curves may be used for the preliminary stability assessment of sloping grounds in liquefiable soils in which a significant static shear stress component is present after the end of the ground shaking, such as in the case of the Lower San Fernando Dam discussed in the paper. 


\section{Acknowledgements}

The first author acknowledges the funding received from the Iraqi Ministry of Higher Education and Scientific Research (MOHESR) in support of his $\mathrm{PhD}$ studies at the University of Manchester. All authors acknowledge the technical support provided by the personnel at the Surrey Advanced Geotechnical Engineering (SAGE) laboratory. In particular they wish to thank Mr George Nikitas and Dr Mehdi Rouholamin for their guidance during the preparation and execution of the laboratory tests.

\section{References}

Been, K. \& Jefferies, M.G. (1985). A state parameter for sands. Gèotechnique, 35(2), 99-112.

Bhattacharya, S., Orense, R. \& Lombardi, D.(2019). Seismic Design of Foundations: Concepts and Applications. ICE Publishing. London, UK.

Broughton, A.T., Van Arsdale, R.B. \& Broughton, J.H. (2001). Liquefaction susceptibility mapping in the city of Memphis and Shelby County, Tennessee. Engineering Geology, 62(1-3), 207-222.

Casagrande, A. (1936). Characteristics of cohesionless soils affecting the stability of earth fills, Journal of Boston Society of Civil Engineers, 23, 257276.

Castro, G. \& Poulos, S.J. (1994). Factors affecting liquefaction and cyclic mobility, Journal of Geotechnical Engineering Division, 103(6), 501-516. 
Castro, G., Seed, R.B., Keller, T.O. \& Seed, H.B. (1992). Steady-state strength analysis of lower San Fernando Dam slide. Journal of Geotechnical Engineering, 118(3), 406-427.

Dafalias, Y.F. \& Manzari, M.T. (2004). Simple plasticity sand model accounting for fabric change effects. Journal of Engineering Mechanics, 130(6), $622-634$.

Dash, S. (2010). Lateral pile-soil interaction in liquefiable soils. PhD Thesis, University of Oxford, Oxford, UK.

Desrues, J., Chambon, R., Mokni, M., \& Mazerolle, F. (1996). Void ratio evolution inside shear bands in triaxial sand specimens studied by computed tomography, Gèotechnique, 46(2), 529-46.

Elgamal, A.W., Zeghal, M., \& Parra, E (1996). Liquefaction of reclaimed island in Kobe, Japan. Journal of Geotechnical Engineering, 122(1),39-49.

Hazen, A. (1918). A study of the slip in the Calaveras Dam. Engineering News Record, 81, No. 26, 1158-1164.

Hazen, A. (1920). Hydraulic fill dams. Transactions of the American Society of Civil Engineers, 83, 1713-1764.

Huang, Y., Hu, H. \& Xiong, M. (2018). Probability density evolution method for seismic displacement-based assessment of earth retaining structures. Engineering Geology, 234, 167-173.

Jefferies, M.G. (1993). Nor-Sand: a simple critical state model for sand. Gèotechnique, 43(1), 91-103. 
Jefferies, M.G. \& Shuttle, D.A. (2002). Dilatancy in General Cambridge-Type Models, Gèotechnique, 52(9), 625-638.

Jefferies, M.G. \& Been, K. (2015). Soil Liquefaction: A Critical State Approach. CRC Press, Taylor \& Francis Group, FL, United States.

Juang, C.H., Zhang, J., Khoshnevisan, S., \& Gong, W. (2017). Probabilistic methods for assessing soil liquefaction potential and effect. Geo-Risk 2017, Denver, Colorado, June 4-7, 2017.

Koppejan, A.W., van Wamelen, B.M., \& Weinberg, L.J.H. (1948). Coastal flow slides in the Dutch province of Zeeland. In Proceedings of the Second International Conference on Soil Mechanics and Foundation Engineering, 5(89-96), Rotterdam, the Netherlands.

Ishihara, K. (1993). Liquefaction and flow failure during earthquakes. Gèotechnique, 43(3), 351-451.

Kiku, H. \& Tsujino, S. (1996). Post liquefaction characteristics of sand. Proceedings 11th World Conference on Earthquake Engineering, Paper No. 1088, Acapulco, Mexico.

Kokusho, T., Hara, T. \& Hiraoka, R. (2004). Undrained shear strength of granular soils with different particle gradations. J. Geotech. Geoenviron. Engng, 130(6), 621-629.

Lee, D.H., Ku, C.S. \& Yuan, H. (2004) A study of the liquefaction risk potential at Yuanlin, Taiwan. Engineering Geology, 71(1-2), 97-117. 
Li, X.S. \& Wang, Y. (1998). Linear representation of steady-state line for sand. Journal of Geotechnical and Geoenvironmental Engineering, 124(12), 1215-1217.

Lombardi, D. \& Bhattacharya, S. (2014). Modal analysis of pile-supported structures during seismic liquefaction. Earthquake Engineering \& Structural Dynamics, 43(1), 119-138.

Lombardi, D., Bhattacharya, S., Hyodo, M. \& Kaneko, T. (2014). Undrained behaviour of two silica sands and practical implications for modelling SSI in liquefiable soils. Soil Dynamics and Earthquake Engineering, 66, 293-304.

Lombardi, D. \& Bhattacharya, S. (2016). Evaluation of seismic performance of pilesupported models in liquefiable soils. Earthquake Engineering 8 Structural Dynamics, 45(6), 1019-1038.

Lombardi, D., Dash, S.R., Bhattacharya, S., Ibraim, E., Wood, D.M. \& Taylor, C.A. (2017). Construction of simplified design p-y curves for liquefied soils. Gèotechnique, 67(3), 216-227.

Middlebrooks, T.A. (1940). Fort Peck slide. Transactions of the ASCE, 107 (Paper 2144), 723-764.

Obermeier, S.F., Olson, S.M. \& Green, R.A. (2005) Field occurrences of liquefaction-induced features: a primer for engineering geologic analysis of paleoseismic shaking. Engineering Geology, 76(3-4), 209-234.

Papathanassiou, G., Ganas, A. \& Valkaniotis, S. (2016) Recurrent liquefaction-induced failures triggered by 2014 Cephalonia, Greece earth- 
quakes: spatial distribution and quantitative analysis of liquefaction potential. Engineering Geology, 200, 18-30.

Pokhrel, R.M., Kuwano, J. \& Tachibana, S. (2013) A kriging method of interpolation used to map liquefaction potential over alluvial ground, Engineering geology, 152(1), 26-37.

Roscoe, K., Schofield, A.N. and Wroth, C.P (1958). On the yielding of soils. Gèotechnique, 8(1), 22-53.

Salvatore, E, Modoni, G., Andó, E, Albano, M., Viggiani, G. (2017). Determination of the critical state of granular materials with triaxial tests. Soils and Foundations, 57(5), 733-744.

Schofield, A., \& Wroth, C.P. (1968). Critical State Soil Mechanics, McGrawHill, London, UK.

Seed, H.B. \& Idriss, I.M. (1967). Analysis of soil liquefaction: Niigata earthquake. Journal of the Soil Mechanics and Foundations Division, 93(3), 83-108.

Seed, H.B., Idriss, I.M., Lee, K.L. \& Makdisi, F.I. (1973). Dynamic analysis of the slide in the Lower San Fernando Dam during the earthquake of February 9, 1971. Report No. EERC 73-2, Earthquake Engineering Research Centre, University of California, California, United States.

Seed, H.B. (1979). Considerations in the earthquake-resistant design of earth and rockfill dams. Gèotechnique, 29(3), 215-263. 
Seed, H.B. (1987). Design problems in soil liquefaction. Journal of Geotechnical Engineering, 113(8), 827-845.

Seed, R.B., Harder, L.F., \& Jong, H.L. (1988). Re-evaluation of the slide in the Lower San Fernando Dam in the 1971 San Fernando Earthquake.Report No. UCBIEERC-88104, University of California, California, United States.

Shen, M., Juang, C.H., \& Ku, C.S. \& Khoshnevisan, S. (2019a). Assessing effect of dynamic compaction on liquefaction potential using statistical methodsa case study. Georisk: Assessment and Management of Risk for Engineered Systems and Geohazards, 1-8.

Shen, M., Juang, C.H. \& Chen, Q. (2019b). Mitigation of liquefaction hazard by dynamic compaction-a random field perspective. Canadian Geotechnical Journal,(In press).

Sitharam, T.G., Vinod, J.S. \& Ravishankar, B.R. (2009). Post-liquefaction undrained monotonic behaviour of sands: experiments and DEM simulations. Gèotechnique, 59(9), 739-749.

Terzaghi, K. \& Peck, R.B. (1948). Soil Mechanics in Engineering Practice. New York Wiley and Sons, United States.

Vaid, Y.P. \& Thomas, J.(1995). Liquefaction and post liquefaction behavior of sand. Journal of Geotechanical Engineering, 121(2), 163-173.

Yamada, G. (1966). Damage to earth structures and foundations by the Niigata Earthquake June 16, 1964. Soils and Foundations, 6(1) 1-13. 
1 Yasuda, S., Masuda, T., Yoshida, N., Nagase, H., Kiku, H., Itafuji, S., Mine, K. \& Sato, K. (1994). Torsional shear and triaxial compression tests on deformation characters of sands before and after liquefaction. Proceedings of the 5th USJapan workshop on earthquake resistant design of lifelines and countermeasures against soil liquefaction, 249-265, Salt Lake City, UT, United States.

Yoshida, N., Yasuda, S., Kiku, M., Masuda, T. \& Finn, W.D.L. (1994). Behaviour of sand after liquefaction. Proceedings of the USJapan workshop on earthquake resistant design of lifeline facilities and countermeasures against soil liquefaction, 5, 181-198, Buffalo,NY, United States.

Youd, T.L. (1973). Liquefaction, flow, and associated ground failure (No. 688). US Geological Survey, United States. 